From: American Journal of Physiology, 270: R978-R983, 1996.

\title{
Effects of food deprivation on induction of neural progestin receptors by estradiol in Syrian hamsters
}

\author{
YUE DU, GEORGE N. WADE, AND JEFFREY D. BLAUSTEIN \\ Neuroscience and Behavior Program and Department of Psychology, Box 37710, \\ University of Massachusetts, Amherst, Massachusetts 01003-7710
}

\begin{abstract}
Du, Y., G. N. Wade, and J. D. Blaustein. Effects of food deprivation on induction of neural progestinreceptors by estradiol in Syrian hamsters. Am. J. Physiol. 270: R978-R983, 1996. — Food deprivation, as well as treatment with metabolic inhibitors, suppresses steroid hormone-induced estrous behavior in ovariectomized (OVX) Syrian hamsters. Previous work indicates that $48 \mathrm{~h}$ of food deprivation decreases the number of detectable estrogen-receptor immunoreactive (ERIR) cells in the ventromedial hypothalamus (VMH) and the area just lateral to it (VLH), increases the number of ERIR cells in the medial preoptic area (MPO), and has no effect on the number of ERIR cells in the nucleus of the solitary tract in OVX hamsters. The present study examined the effects of food deprivation on neural progestin receptor binding using an in vitro binding assay and on progestin receptor immunoreactivity (PRIR) in estradiol-primed, OVX hamsters. Parallel behavior tests for sexual behavior were also performed in both experiments. OVX hamsters received $2.5 \mu \mathrm{g}$ estradiol benzoate (EB) and were fed ad libitum or food deprived at the same time. Forty-eight h later, animals were killed in preparation for the immunocytochemistry or progestin receptor assay. Binding assays indicated that $48 \mathrm{~h}$ food deprivation decreased progestin receptor levels in the preoptic area and had no effect in the mediobasal hypothalamus, an area which includes the VMH and the arcuate nucleus (ARH). Immunocytochemical analysis confirmed these findings. Food deprivation caused a decrease in sexual receptivity and in the number of detectable PRIR cells in the MPO and medial amygdala but had no effect on the number of detectable PRIR cells in the VMH/VLH, the ARH, or the anteroventral periventricular nucleus. These results suggest that food deprivation modulates progestin receptor binding and PRIR in a site-specific manner. In addition, the effects of food deprivation on neural ERIR and PRIR are significantly different.

nutritional infertility, progestin receptor, estrogen receptor, estrous behavior, hamsters, ventromedial hypothalamus, preoptic area
\end{abstract}

MANY ENVIRONMENTAL FACTORS, including food availability, photoperiod, temperature, and social cues, can influence the reproductive performance of mammals. Almost every component of reproduction including puberty, ovulation, reproductive behavior, and lactation demand energy. Therefore, it is not surprising that food availability is one of the most important factors regulating mammalian reproduction (8). In female mammals, undernutrition delays puberty, interrupts menstrual and estrous cycles $(8,30)$ and prevents the occurrence of estrous behavior in a variety of species, including hamsters $(11,17,20)$. The neural mechanisms underlying nutritional infertility have attracted a great deal of interest. Food restriction alters the secretion of pituitary gonadotropins and gonadal steroids. This response is thought to be primarily due to the suppression of $\mathrm{GnRH}$ release $(8,16,23,30)$. The activity of $\mathrm{GnRH}$ neurons in forebrain of underfed hamsters appears to decrease, which is reflected by the suppression of Fos-like immunoreactivity (1). In addition to the influence of metabolic manipulations on reproductive physiology, reproductive behavior is affected through separate mechanisms. It is likely that the suppression of estrous behavior caused by metabolic fuel restriction is due to a disruption of ovarian secretion of estradiol and progesterone and to a reduced neural responsiveness to ovarian steroids. Work from this lab has focused on the second of these possibilities (17).

In ovariectomized (OVX) diabetic rats, acute withdrawal of exogenous insulin diminishes estrous behavior induced by sequential treatment with estradiol and progesterone and is associated with decreased neural estradiol binding $(15,25)$. Furthermore, either diabetes, $48 \mathrm{~h}$ of food deprivation, or treatment with the metabolic inhibitors, 2-deoxy-D-glucose (an inhibitor of glycolysis) and methyl palmoxirate (an inhibitor of fatty acid oxidation), suppresses estrous behavior and causes a significant decrease in estrogen receptor immunoreactivity (ERIR) in ventromedial hypothalamus (VMH) and the area just lateral to it (VLH) in OVX hamsters (17). This work has also shown that manipulations of metabolic fuel 
availability increase ERIR in the medial preoptic area (MPO) and have no effect on ERIR in the nucleus of the solitary tract in OVX hamsters. These findings suggest that suppression of hamster estrous behavior by food deprivation is due, at least in part, to a decrease in ERIR in the VMH/VLH, a critical site involved in regulation of estrous behavior by estradiol and progesterone $(10,12,18,22,26)$.

Given the facilitatory role of progesterone in the expression of estrous behavior in estradiol-primed OVX hamsters (14) and the induction of progestin receptors by estradiol $(13,24)$, it would be extremely interesting to determine the effects of metabolic fuel deprivation on induction of neural progestin receptors by estradiol in hamsters. First, alterations in neural progestin receptors could contribute to the fuel deprivation-induced decrements in estrous behavior. Like many other species, female hamsters are dependent on the actions of both estradiol and progesterone for the induction of sexual behavior under physiological conditions. OVX hamsters do not become receptive with estrogen treatment alone (14) unless it is given chronically or in supraphysiological doses (28). Second, progestin receptors are an excellent cellular marker for the actions of estradiol, and it might be predicted that manipulations that decrease neural ERIR would also dampen the induction of progestin receptors by estradiol treatment $(2,5)$.

In the following experiments, we have focused on the hypothalamus and preoptic area (POA), in order to relate the effects of food deprivation on induction of progestin receptors to expression of estrous behavior. Two approaches were used to examine this relationship, an in vitro binding assay and immunocytochemistry, each of which possesses its own advantages and disadvantages. In general, in vitro ligand binding assays on dissected tissue provide excellent quantitative information about the concentration of receptors in a particular region, while immunocytochemistry, with higher anatomical resolution, allows the cellular localization of receptors $(2,5)$. Our reason for using two different methods to address the same issue was to try to avoid a failure to detect changes which might be due to the limitations of using only a single technique. In addition, congruence of the results using different techniques would increase our confidence in the findings.

\section{METHODS}

\section{Animals and Housing}

Female Lak:LVG Syrian hamsters were purchased from Charles River Breeding Laboratories (Wilmington, MA) and housed individually in stainless-steel wire-bottom cages in a room maintained on a $16: 8 \mathrm{~h} \mathrm{light-dark} \mathrm{cycle} \mathrm{(lights} \mathrm{on} \mathrm{at} 0500$ ) at $22 \pm 2^{\circ} \mathrm{C}$. After arrival at the laboratory, animals were fed Purina Laboratory Rodent Chow pellets (no. 5001) ad libitum unless otherwise noted. Tap water was available at all times. Two weeks before each experiment, animals were bilaterally OVX under pentobarbital sodium anesthesia $(80 \mathrm{mg} / \mathrm{kg})$.

\section{Behavior Testing}

In parallel with binding assays and immunocytochemistry, additional groups of animals ( $n=10$ each) were tested for estrous behavior. Food was removed from one group $2 \mathrm{~h}$ before injection of estradiol benzoate $(\mathrm{EB} ; 2.5 \mu \mathrm{g})$ in $0.1 \mathrm{ml}$ sesame oil. The other group had food freely available. Forty-six h after estradiol treatment all animals received a subcutaneous injection of $500 \mu \mathrm{g}$ progesterone in $0.1 \mathrm{ml}$ sesame oil. The behavior test started $4 \mathrm{~h}$ after progesterone injection. Lordosis was quantified by recording the number of seconds spent in the lordosis posture in $3 \mathrm{~min}$ in the presence of a sexually active male.

\section{In vitro Progestin Receptor Assay}

Tissue preparation and assay protocols in this study were modified from those of Blaustein and Feder (3) done in guinea pigs. All animals were decapitated, and brain tissues were dissected on ice. Dissected tissues were homogenized in $900 \mu \mathrm{l}$ TEGT buffer (10 mM Tris-HCl, $1.5 \mathrm{mM} \mathrm{Na}{ }_{2}$ EDTA, $10 \%$ glycerol, $12 \mathrm{mM}$ monothioglycerol, $\mathrm{pH}$ 7.4) with a Polytron. After centrifugation at 48, $000 \times g$ for $30 \mathrm{~min}, 250 \mu \mathrm{l}$ samples of the supernatant were incubated with $50 \mu \mathrm{l}$ TEGT containing $\left[{ }^{3} \mathrm{H}\right] \mathrm{R} 5020(0.4 \mathrm{nM}$ final concentration) $\pm 1,000$-fold excess radioinert progesterone. After $4 \mathrm{~h}$ incubation at $0^{\circ} \mathrm{C}$, bound $\left[{ }^{3} \mathrm{H}\right] \mathrm{R} 5020$ was separated from free $\left[{ }^{3} \mathrm{H}\right] \mathrm{R} 5020$ by gel filtration on Sephadex LH-20 columns in a cold room $\left(4{ }^{\circ} \mathrm{C}\right)$. Two-hundred-fifty $\mu \mathrm{l}$ of incubate was applied to columns that had been equilibrated with TEGT and was washed into columns with $150 \mu \mathrm{l} \mathrm{TEGT.} \mathrm{Thirty} \mathrm{min} \mathrm{after} \mathrm{applying} \mathrm{samples}$ to columns, bound $\left[{ }^{3} \mathrm{H}\right] \mathrm{R} 5020$ was eluted into scintillation vials with $700 \mu \mathrm{l}$ TEGT. Five $\mathrm{ml}$ of scintillation fluid was added, and radioactivity was counted in a liquid scintillation spectrophotometer. Specific binding was calculated by subtracting nonspecific

binding from total binding. Protein concentration was determined in a sample taken prior to incubation by the method of Bradford (7). Receptor levels were expressed as femtomoles of $\left[{ }^{3} \mathrm{H}\right] \mathrm{R} 5020$ bound per milligram of cytosol protein.

\section{Progestin-Receptor Immunocytochemistry}

The immunocytochemical technique developed for progestin receptor immunoreactivity (PRIR) in guinea pigs was used with 
some modifications (29). Hamsters were deeply anesthetized with pentobarbital sodium (160 mg/ $\mathrm{kg}$ ). Five thousand units of sodium heparin dissolved in $1 \mathrm{ml}$ saline was injected directly into the left ventricle, and the apex of the heart was cut before inserting a cannula through the left ventricle. Normal saline $(75-100 \mathrm{ml})$ preceded the flow of fixative $(2 \%$ acrolein in $0.1 \mathrm{M}$ sodium phosphate buffer, $\mathrm{pH}$ 7.2). The flow rate of the fixative was maintained at $25 \mathrm{ml} / \mathrm{min}$ with a pressure of $100 \mathrm{~mm} \mathrm{Hg}$ for $10 \mathrm{~min}$. Brains were removed and stored overnight at $4^{\circ} \mathrm{C}$ in $0.1 \mathrm{M}$ sodium phosphate containing $20 \%$ sucrose, and $40 \mu \mathrm{m}$ frozen, coronal sections were cut through the POA and hypothalamus.

Free-floating sections were rinsed 3 times for 5 min each with $0.05 \mathrm{M}$ Tris-buffered saline (TBS; pH 7.6) followed by $1 \%$ sodium borohydride in TBS for $10 \mathrm{~min}$ to remove residual aldehydes. After 4 rinses in $0.05 \mathrm{M} \mathrm{TBS}$ for $5 \mathrm{~min}$ each, sections were incubated for $20 \mathrm{~min}$ in TBS with $1 \%$ hydrogen peroxide, $1 \%$ bovine serum albumin, and $20 \%$ rabbit serum to deplete endogenous peroxidase activity and decrease nonspecific staining. The sections then were incubated for $72 \mathrm{~h}$ in primary antibody (B39, raised in rat, Abbott Laboratories) at a concentration of $0.1 \mu \mathrm{g} /$ $\mathrm{ml}$ in TBS with $0.02 \%$ sodium azide, $0.05 \%$ Triton $\mathrm{X}-100$, and $0.1 \%$ gelatin $(\mathrm{pH} 7.6)$ at $4^{\circ} \mathrm{C}$.

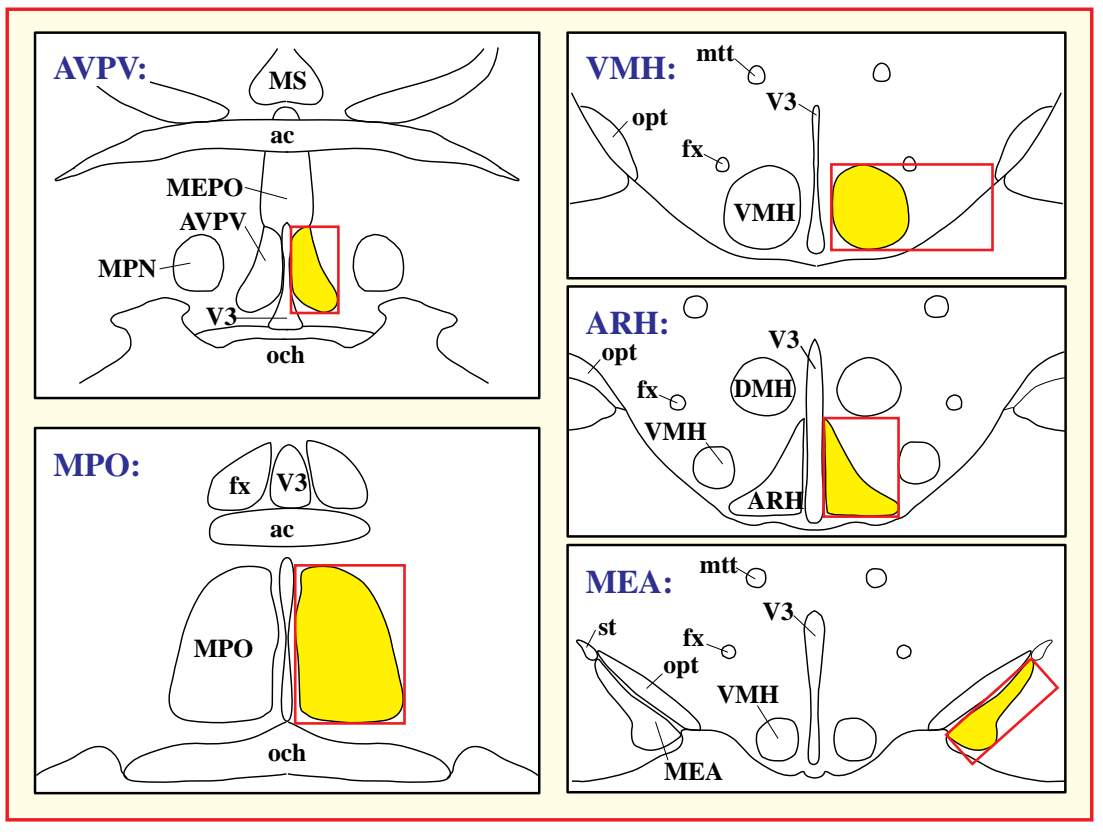

Fig. 1. Camera lucida drawings indicating neural sites where PRIR was detected and counted (bold rectangles) in hamster brains. Key: ac, anterior commissure; ARH, arcuate nucleus of the hypothalamus; AVPV, anteroventral periventricular nucleus of the hypothalamus; DMH, dorsomedial nucleus of the hypothalamus; fx, columns of the fornix; MEA, medial nucleus of the amygdala; MEPO, median preoptic nucleus; MPN, medial preoptic nucleus; MPO, medial preoptic area; MS, medial septal nucleus; mtt, mammillothalamic tract; och, optic chiasm; opt, optic tract; st, stria terminalis; V3, third ventricle; VMH, ventromedial nucleus of the hypothalamus.

Following 3 rinses in the same buffer at room

temperature, sections were incubated for $90 \mathrm{~min}$ in secondary antiserum (biotinylated rabbit antirat immunoglobulin, Vector Laboratories, Burlingame, CA), diluted in the same buffer as the primary antibody at a concentration of $0.5 \mu \mathrm{g} / \mathrm{ml}$. The sections then were rinsed with the same buffer twice followed by a TBS wash for $5 \mathrm{~min}$. The sections were incubated for $90 \mathrm{~min}$ in streptavidin reagent (Elite ABC kit, Vector Laboratories) diluted at a concentration of 1:100 in TBS. Following the incubations with antibodies, sections were treated with diaminobenzidine $(0.05 \%$ in TBS) in the presence of hydrogen peroxide $(0.05 \%)$ and washed in TBS. The immunostained tissue sections were then mounted on slides, coverslipped, and analyzed by a computer-aided imaging technique.

\section{Computer-Aided Image Analysis}

Two adjacent sections were chosen from each area (except for the anteroventral periventricular nucleus (AVPV), for which only one matched section was available) by carefully matching their landmarks under darkfield illumination. The number of PRIR cells was counted in rectangular boxes that included each area(Fig. 1). The Image 1.47 program (W. Rasbad, NIH) was used for all image processing and analysis as described previously $(17,19)$.

\section{Data Analysis}

Data from each experiment were analyzed by one- or two-way analyses of variance. Results were considered statistically significant if $P<0.05$.

\section{Procedures}

Experiment 1: Two weeks following OVX, animals were prepared for the in vitro binding assay. Thirty-two hamsters were assigned to one of four groups. Forty-eight h food-deprived (food removed $2 \mathrm{~h}$ before estradiol injection) or ad libitum-fed OVX hamsters were injected with EB $(2.5 \mu \mathrm{g})$ or $0.1 \mathrm{ml}$ sesame oil vehicle and decapitated $46 \mathrm{~h}$ later. Mediobasal hypothalamus (MBH) and POA were dissected separately. The MBH samples included the VMH, the ventrolateral hypothalamus, and the arcuate nucleus (ARH). The POA samples included the preoptic area and a small portion of bed nucleus of the stria terminalis (BNST). An additional 20 animals were used to conduct the parallel behavior experiment.

Experiment 2: Two weeks after OVX, animals were prepared for immunocytochemistry. Food-deprived ( $n=6$; food removed $2 \mathrm{~h}$ before EB injection) or ad libitum-fed $(n=6)$ OVX hamsters were injected with EB $(2.5 \mu \mathrm{g})$ and perfused with $2 \%$ acrolein 46 $\mathrm{h}$ later. A parallel behavior experiment was conducted as in experiment 1 . 
Fig. 2. Effects of $48 \mathrm{~h}$ food deprivation on $\mathrm{EB}+\mathrm{P}$-induced estrous behavior and in vitro cytosolic binding of $\left[{ }^{3} \mathrm{H}\right] \mathrm{R} 5020$ in mediobasal hypothalamus and preoptic area of ovariectomized hamsters. Bars with different letters are significantly different, $P<0.05$.

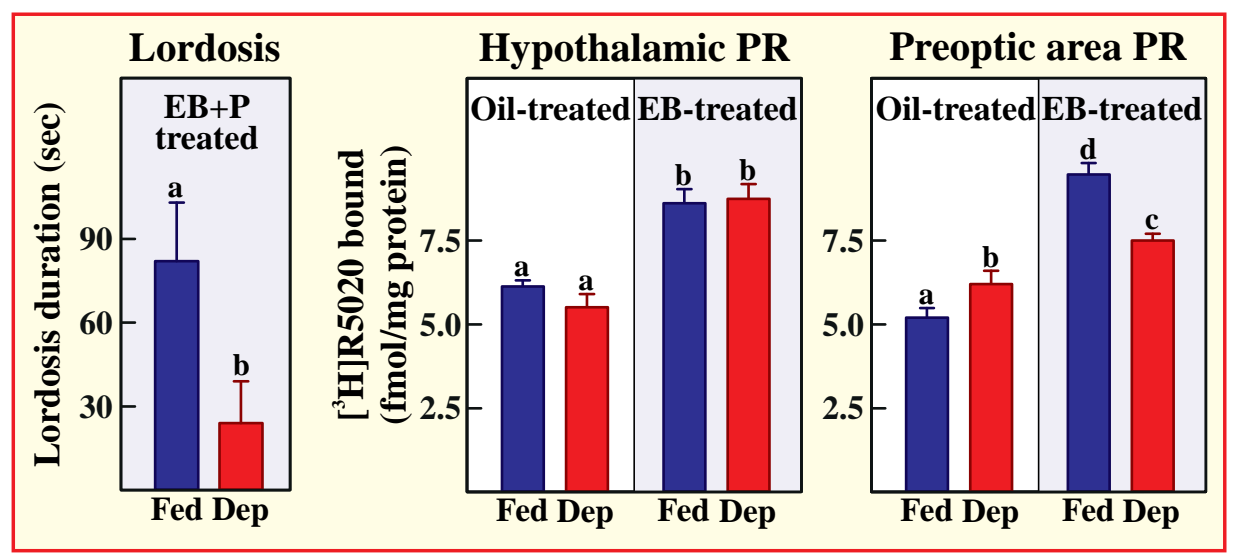

\section{RESULTS}

\section{Experiment 1: Effect of food deprivation on neural [ $\left.{ }^{3} H\right] R 5020$ binding}

In both fed and food-deprived OVX hamsters, treatment with estradiol significantly increased progestin receptor levels over basal levels in the MBH and preoptic area $(P<0.001)$ (Fig. 2). In the oil-treated controls, $48 \mathrm{~h}$ food deprivation had no effect on the basal levels of progestin receptors in the MBH but increased the progestin receptor binding level by $19 \%$ in the POA $(P<0.05)$. In estradiol-treated groups, $48 \mathrm{~h}$ food deprivation caused a significant $(P<0.001)$ decrease in progestin receptor binding in the POA $(-20 \%)$, but there was no effect of food deprivation on progestin receptor in the $\mathrm{MBH}$.

Parallel behavioral tests showed a $71 \%$ decrease in lordosis duration after $48 \mathrm{~h}$ food deprivation $(P<0.05)$ (Fig. 2), consistent with previous reports $(11,17)$.

\section{Experiment 2: Effect of food deprivation on PRIR}

Before examining the effects of food deprivation on PRIR, we mapped the distribution of PRIR-containing cells in hamster forebrain. Without the injection of EB, almost no PRIR-containing cells were found in OVX hamster forebrain. After priming with EB, PRIRcontaining cells were evident in MPO, VMH/VLH, BNST, medial amygdala (MEA), and ARH. PRIR was present primarily in cell nuclei as reported in guinea pigs (4). Among these areas, the denseststaining and greatest number of PRIR cells were found in the MPO. The BNST, the AVPV, the ARH, and the VMH/VLH contained a moderate numbers of PRIR cells (Figs. 1 and 3). There were only a few PRIR-containing cells observed in the amygdala, all in the posterodorsal portion of the MEA. PRIR-containing cells in the paraventricular nucleus of the hypothalamus could only be seen clearly at higher concentrations of primary antibody (at least $0.2 \mu \mathrm{g}$ / $\mathrm{ml}$ for B39).

As in experiment 1, in EB-treated animals, $48 \mathrm{~h}$ food deprivation had no effect on the number of detectable PRIR-containing cells either in the VMH/VLH or the ARH (Fig. 4), the two areas which comprise the major part of the MBH dissection. The number of PRIRcontaining cells in the MPO was decreased $(P<0.05)$ after food deprivation, also consistent with the results from the in vitro binding assay. The number of PRIR-containing cells in the AVPV did not differ between these two groups. A significant decrease in the number of PRIR cells was observed in the MEA in the food-deprived group compared with ad libitum-fed controls $(P<0.001)$. As in experiment

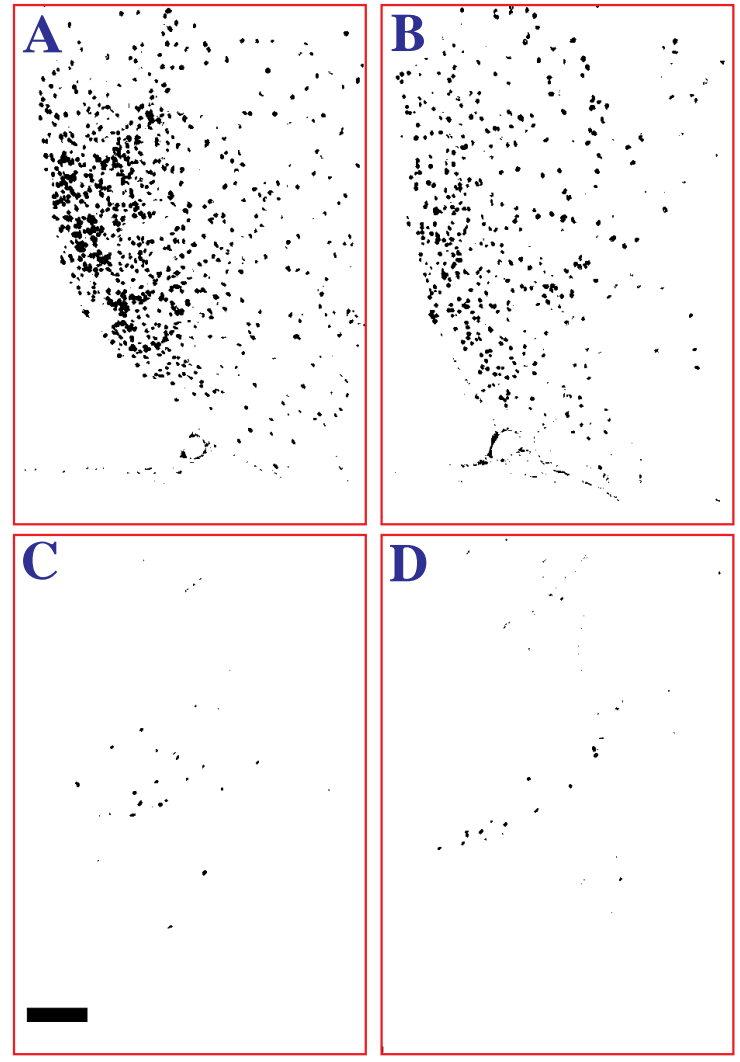

Fig. 3. Progestin receptor immunostaining (B39 antibody) in sections from the medial preoptic area (A, B) and ventromedial/ventrolateral hypothalamus $(C, D)$ of ovariectomized hamsters primed with estradiol benzoate. Animals were either fed ad libitum (A, C) or food deprived (B, D) for $48 \mathrm{~h}$ prior to perfusion. Magnification bar $=100 \mu \mathrm{m}$. 


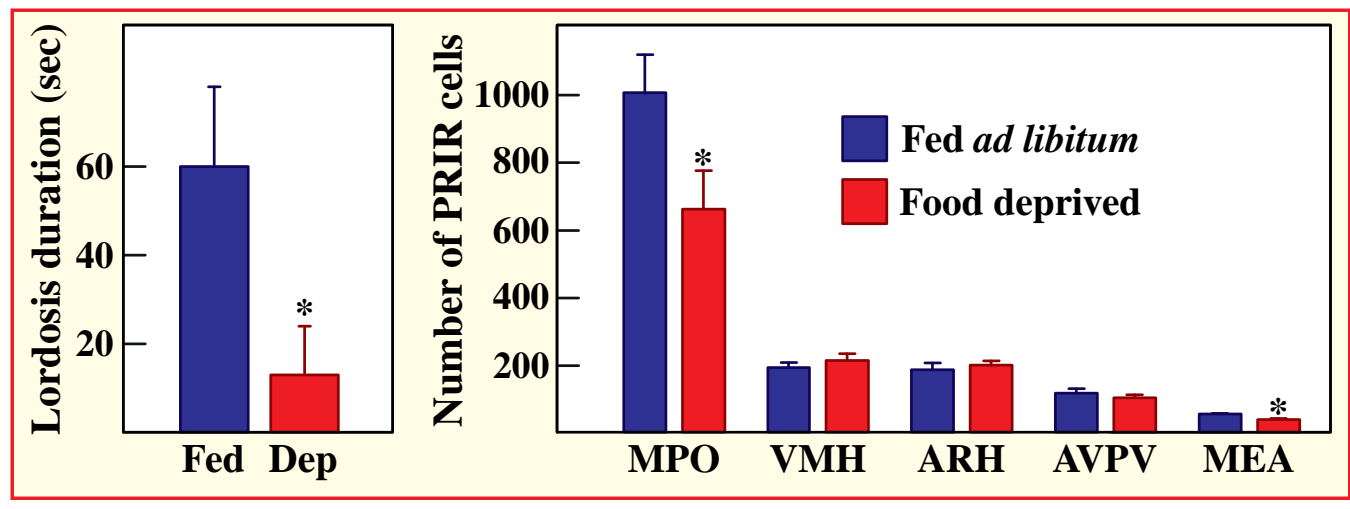

Fig. 4. Effects of $48 \mathrm{~h}$ food deprivation on $\mathrm{EB}+\mathrm{P}$-induced estrous behavior and the number of detectable PRIR cells in several neural regions in estradiol-treated OVX hamsters. * $P<0.05$ versusad libitium-fed controls.

$1,48 \mathrm{~h}$ of food deprivation significantly inhibited steroid-induced estrous behavior (Fig. 4).

\section{DISCUSSION}

In experiment 1 , food deprivation diminished induction of progestin receptors in the POA by estradiol in OVX hamsters and had no effect in the MBH in either the estradiol- or oil-treated groups. In contrast, food deprivation increased progestin receptor levels in the POA in oil-treated animals. These findings indicate that the effects of food deprivation on progestin receptor levels are estrogen-dependent in the POA, but not in the MBH. Experiment 2 produced similar results using immunocy tochemical detection of PRIR. Food deprivation decreased the number of detectable PRIR cells in both the MPO and the MEA and had no effect in the VMH/VLH, ARH, or the AVPV in estradiol-treated animals. This experiment not only confirmed the results from the in vitrobinding assay, but also provided greater anatomical resolution.

Experiment 2 also mapped the distribution of PRIR in hamster forebrain. The highest density of PRIR-containing cells was seen in the MPO and the ARH. Moderate progestin receptor immunostaining was found in the BNST, VMH/ VLH, and the AVPV. There were only a few PRIR-containing cells detected in the MEA. These results are in agreement with the distribution of progestin receptors previously reported using autoradiography in hamster brain (21), immunocytochemical studies in guinea pigs (4) and rats (Blaustein, unpublished observations).

The results support the hypothesis that the concentration of neural progestin receptors is sensitive to metabolic fuel availability and is decreased in MPO and MEA of food-deprived, estrogen-treated hamsters. An unexpected finding is that food deprivation had no effect on progestin receptor binding in the MBH or on PRIR in the VMH/VLH, an area important for estradiol and progesterone facilitated estrous behavior.

There are several possible interpretations to account for the lack of change in VMH/VLH progestin receptors in the face of the food deprivation-induced suppression of estrous behavior. First, there could be fuel deprivation-induced decreases in VMH/VLH progestin receptors that went undetected. This is unlikely given that both receptor binding and immunocytochemical analysis failed to detect any changes in VMH/VLH progestin receptors, although we cannot exclude this possibility at this time.

Second, the contribution of progesterone to the inhibition of estrous behavior caused by metabolic fuel deprivation might be due to the alterations of progestin receptors in areas other than the VMH/VLH. Induction of estrous behavior is thought to involve concurrent progesterone action in a number of different neural sites, and a change in progestin receptors in any of these areas could affect the behavior. For example, the decreases in POA progestin receptors could contribute to the inhibition of estrous behavior by food deprivation, because it has been reported that progesterone can act in the POA as well as the VMH to facilitate estrous behavior in hamsters (27).

Third, food deprivation-induced changes in behavioral responsiveness to steroid hormones might involve changes in nongenomic mechanisms of progesterone action. For example, in hamsters the midbrain ventral tegmental area is an important site for facilitation of estrous behavior by progesterone, perhaps through nongenomic mechanisms (9). The present experiments were not designed to examine possible changes in this type of progesterone action.

Fourth, it is conceivable that inhibition of estrous behavior by metabolic fuel deprivation does not involve changes in neural responsiveness to progesterone. That is, the inhibition could be due entirely to decreases in neural estrogen receptor and/or to steroid-receptor-independent mechanisms.

Another unexpected finding was the lack of congruence between deprivation-induced changes in estrogen and progestin receptors. In the VMH/VLH, food deprivation decreases estrogen receptors (17) but has no effect on progestin 
receptors in EB-treated animals (Figs. 2 and 4). In the MPO, food deprivation increases ERIR (17), but there is a significant decrease in PRIR (Figs. 2 and 4). Once again, there are several possible interpretations.

First, steroid-receptor-containing neurons are heterogeneous. For example, although virtually all neurons containing estrogen-induced PRIR contain ERIR, not all ERIR-containing neurons contain PRIR (6). A fascinating possibility is that metabolic fuel deprivation could affect levels of ERIR primarily (or only) in neurons that do not contain progestin receptors.

Second, in the POA metabolic fuel availability could diminish induction of progestin receptors in the face of increased ERIR by altering some event(s) that occur subsequent to estradiol binding to its receptors. There are multiple molecular events between occupation of estrogen receptors and production of progestin receptors, and any of these steps could be sensitive to information regarding energy availability.

Third, it is conceivable that although VMH/VLH ERIR is reduced somewhat following food deprivation there is still a sufficient level of estrogen receptor remaining to mediate normal induction of progestin receptors. Currently the cellular levels of estrogen receptors that are sufficient for induction of progestin receptors remain unknown.

In summary, the present results indicate that induction of progestin receptors by estradiol is dampened by $48 \mathrm{~h}$ of food deprivation in POA and MEA, but not in the other neural sites that were examined. Furthermore, these consequences of metabolic fuel deprivation on neural progestin receptors stand in contrast to the effects on neural ERIR observed previously (17).

Supported by Research Grants NS10873 and NS19327, by Research Scientist Award MH00321, and by Research Scientist Development Award MH00885 from the National Institutes of Health. We are grateful to Robin Lempicki, Joanne Turcotte, and Jay Alexander for their expert technical assistance and to Brad Powers for his advice on the manuscript.

\section{REFERENCES}

1. Berriman, S. J., G. N. Wade, and J. D. Blaustein. Expression of Fos-like proteins in gonadotropin-releasing hormone neurons of Syrian hamsters: Effects of estrous cycles and metabolic fuels. Endocrinology 131: 2222-2228, 1992.

2. Blaustein, J. D. Modulation of sex steroid receptors by neurotransmitters: Relevant techniques. Neuroprotocols 1: 42-51, 1992.

3. Blaustein, J. D., and H. H. Feder.Cytoplasmic progestin receptors in guinea pig brain: Characteristics and relationship to the induction of sexual behavior. Brain Res. 169: 481-497, 1979.

4. Blaustein, J. D., J. C. King, D. O. Toft, and J. C. Turcotte.Immunocytochemical localization of estrogen-induced progestin receptors in guinea pig brain. Brain Res. 474: 1-15, 1988.

5. Blaustein, J. D., M. J. Tetel, K. H. N. Ricciardi, Y. Delville, and J. C. Turcotte. Hypothalamic ovarian steroid hormonesensitive neurons involved in female sexual behavior. Psychoneuroendocrinology 19: 505-516, 1994.

6. Blaustein, J. D., and J. C. Turcotte.Estradiol-induced progestin receptor immunoreactivity is found only in estrogen receptor immunoreactive cells in the guinea pig brain. Neuroendocrinology 49: 454-461, 1989.

7. Bradford, M. M. A rapid and sensitive method for quantification of microgram quantities of protein utilizing the principle of protein-dye binding. Anal. Biochem. 72: 248-254, 1976.

8. Bronson, F. H. Mammalian Reproductive Biology. Chicago: University of Chicago Press, 1989,

9. Debold, J. F., and C. A. Frye. Progesterone and the neural mechanisms of hamster sexual behavior. Psychoneuroendocrinology 19: 563-579, 1994.

10. Debold, J. F., C. W. Malsbury, V. S. Harris, and V. Malenka. Sexual receptivity: Brain sites of estrogen action in female hamsters. Physiol. Behav. 29: 589-593, 1982.

11. Dickerman, R. W., H.-Y.Li, and G. N. Wade.Decreased availability of metabolic fuels suppresses estrous behavior in Syrian hamsters. Am. J. Physiol. 264: R568-R572, 1993.

12. Floody, O. R., N. E. Blinn, R. D. Lisk, and A. J. Vomachka. Localization of hypothalamic sites for the estrogen-priming of sexual receptivity in female hamsters. Behav. Neurosci. 101: 309-314, 1987.

13. Fraile, I. G., D. W. Pfaff, and B. S. McEwen. Progestin receptors with and without estrogen induction in male and female hamster brain. Neuroendocrinology 45: 487-491, 1987.

14. Frank, A. H., and R. M. Fraps. Induction of estrus in the ovariectomized golden hamster. Endocrinology 37: 357-361, 1945.

15. Gentry, R. T., G. N. Wade, and J. D. Blaustein. Binding of $\left[{ }^{3} \mathrm{H}\right]$ estradiol by brain cell nuclei and female rat sexual behavior: inhibition by experimental diabetes. Brain Res. 135: 135-146, 1977.

16. I'Anson, H., D. L. Foster, G. R. Foxcroft, and P. J. Booth. Nutrition and reproduction. Oxford Rev. Reprod. Biol. 13: 239$311,1991$.

17. Li, H.-Y., G. N. Wade, and J. D. Blaustein. Manipulations of metabolic fuel availability alter estrous behavior and neural 
estrogen receptor immunoreactivity in Syrian hamsters. Endocrinology 135: 240-247, 1994.

18. Meisel, R. L., G.P. Dohanich, B.S. McEwen, and D. W.Pfaff.Antagonism of sexual behavior in female rats by ventromedial hypothalamic implants of antiestrogen. Neuroendocrinology 45: 201-207, 1987.

19. Meredith, J. M., C. J. Auger, and J. D. Blaustein. Down-regulation of estrogen receptor immunoreactivity by $17 ß-$ estradiol in the guinea pig forebrain. J. Neuroendocrinol. 6: 639-648, 1994.

20. Morin, L. P. Environment and hamster reproduction: responses to phase-specific starvation during estrous cycle. Am. $J$. Physiol. 251: R663-R669, 1986.

21. Munn, A. R., M. Sar, and W. E.Stumpf. Topographic distribution of progestin target cells in hamster brain and pituitary after injection of $\left[{ }^{3} \mathrm{H}\right] \mathrm{R} 5020$. Brain Res. 274: 1-10, 1983.

22. Rubin, B. S., and R. J. Barfield. Priming of estrous responsiveness by implants of $17 \mathrm{~b}$-estradiol in the ventromedial hypothalamic nucleus of rats. Endocrinology 106: 504-509, 1980.

23. Schillo, K. K. Effects of dietary energy on control of luteinizing hormone secretion in cattle and sheep.J. Anim. Sci. 70: 12711282, 1992.

24. Siegel, H. I., A. Senatore, S. Rogers, and H. B. Ahdieh. Sexual receptivity in hamsters: Brain nuclear estrogen and cytosolic progestin receptors after single and multiple steroid treatments during the estrous cycle. Horm. Behav. 23: 173-184, 1989.

25. Siegel, L. I., and G. N. Wade. Insulin withdrawal impairs sexual receptivity and retention of brain cell nuclear estrogen receptors in diabetic rats. Neuroendocrinology 29: 200-206, 1979.

26. Takahashi, L. K. Hormonal regulation of sociosexual behavior in female mammals. Neurosci. Biobehav. Rev. 14: 403-413, 1990.

27. Takahashi, L. K., and R. D. Lisk. Dual progesterone action in diencephalon facilitates the induction of sexual receptivity in estrogen-primed golden hamsters. Physiol. Behav. 44: 741-747, 1988.

28. Tiefer, L. Gonadal hormones and mating behavior in the adult golden hamster. Horm. Behav. 1: 189-202, 1970.

29. Turcotte, J. C., and J. D. Blaustein. Immunocytochemical localization of midbrain estrogen receptor-containing and progestin receptor-containing cells in female guinea pigs. J. Comp. Neurol. 328: 76-87, 1993.

30. Wade, G. N., J. E. Schneider, and H.-Y. Li. Control of fertility by metabolic cues. Am. J. Physiol. 270: E1-E19, 1996.

For digital (color) version in Adobe Acrobat format (.PDF), contact George Wade or download from http://www-vms.oit.umass.edu/ gwade/index.html 